\title{
KILKA UWAG NA TEMAT DOLICZANIA DAROWIZN DO SUBSTRATU ZACHOWKU
}

Naczelną zasadą polskiego prawa spadkowego jest zasada swobody testowania, która oznacza, że każda osoba posiadająca zdolność testowania może poprzez sporządzenie testamentu rozporządzić swoim majątkiem na wypadek śmierci. W testamencie do spadku może zostać powołana osoba zaliczająca się do kręgu osób najbliższych spadkodawcy (dzieci, małżonkowie) lub spoza tego kręgu (w tym osoby prawne oraz jednostki organizacyjne nieposiadające osobowości prawnej, ale wyposażone w zdolność prawną) $)^{1}$. Powyższe oznacza, że osoby najbliższe spadkodawcy (dzieci oraz małżonek) mogą zostać wykluczone od dziedziczenia, a do spadku zostanie powołana osoba obca z punktu widzenia więzi pokrewieństwa. Spadkodawca może również powołać do dziedziczenia tyko niektóre z osób najbliższych. Taka sytuacja niewątpliwie skutkuje pokrzywdzeniem osób najbliższych spadkodawcy lub niektórych z tych osób. W orzecznictwie przyjmuje się, że testament, z uwagi na pominięcie w kręgu spadkobierców osób najbliższych dla spadkodawcy, nie może zostać uznany za sprzeczny z prawem lub zasadami współżycia

* Doktorant, Uniwersytet Śląski w Katowicach; adwokat, Okręgowa Izba Adwokacka w Katowicach; e-mail: odilon@interia.pl, ORCID ID: https://orcid.org/0000-0002-2295023X.

1 Zaznaczam jednak, że rozporządzenie majątkiem na wypadek śmierci może zostać również dokonane w drodze innych czynności prawnych niż testament, przy czym rozporządzenia te dotyczą poszczególnych składników majątkowych (np. dysponowanie wkładem bankowym na wypadek śmierci - art. 56 ustawy z dnia 29 sierpnia 1997 r. Prawo bankowe, tekst jednolity: Dz. U. z 2019 r. poz. 2357), podczas gdy powołanie do dziedziczenia ma charakter generalny. 
społecznego ${ }^{2}$. W doktrynie jednak pojawiło się stanowisko, że w szczególnie wyjątkowych sytuacjach pominięcie w testamencie osób najbliższych może zostać uznane - w świetle zakorzenionego w społeczeństwie sytemu wartości - za tak rażąco niesprawiedliwe, że zasadne będzie uznanie testamentu za nieważny jako sprzeczny z zasadami współżycia społecznego ${ }^{3}$.

Celem instytucji zachowku uregulowanej w przepisach art. 991-1011 Kodeksu cywilnego ${ }^{4}$ jest zabezpieczenie w minimalnym zakresie praw do spadku osób najbliższych spadkodawcy ${ }^{5}$. Przepisy o zachowku stanowią zatem ograniczenie zasady swobody testowania ${ }^{6}$. Pozostawanie $w$ re-

2 Zob. wyrok SN z dnia 9 lutego 1960 r., I CR 365/60, OSPiKA 1962, nr 3, poz. 74.

3 Zob. S. Wójcik, F. Zoll, Testament, Studia Prawa Prywatnego 2006, z. 2; A. Dyoniak, Ochrona rodziny w razie śmierci jednego z matżonków, Warszawa-Poznań 1990, s. 81. W mojej ocenie taka sytuacja mogłaby mieć miejsce wyłącznie wówczas, gdyby po zrealizowaniu roszczenia o zachowek osoby pominiętej, jej sytuacja w okolicznościach konkretnej sprawy nadal jawiła się jako szczególnie trudna. Tytułem przykładu można wskazać sytuację, gdy ojciec samotnie wychowujący ciężko chore dziecko, które wymaga specjalistycznego leczenia i w związku z tym znacznych nakładów finansowych, powołuje w testamencie swoją konkubinę, która nie miała i nie ma jakiegokolwiek wkładu w opiekę nad dzieckiem spadkodawcy, a jednocześnie mimo wykonania roszczenia o zachowek sytuacja materialna dziecka nadal byłaby bardzo trudna, chociażby mając na uwadze konieczność przeprowadzenia kosztowej operacji, a następnie dalszego leczenia i rehabilitacji dziecka. Jednocześnie spełnione musiałyby być dwa dodatkowe warunki. Po pierwsze, nie byłoby innych osób bliskich, oprócz spadkodawcy, zobowiązanych do dostarczenia dziecku niezbędnych kosztów utrzymania lub możliwości majątkowe i zarobkowe tych osób byłyby znacznie niższe niż spadkodawcy, a jednocześnie nie pozwalałyby na zaspokojenie nawet w minimalnym zakresie podstawowych potrzeb dziecka, którego stan zdrowia nie rokowałby poprawą w przyszłości. Po drugie, sytuacja materialna spadkobiercy (jego możliwości majątkowe i zarobkowe) byłaby oczywiście lepsza niż sytuacja pominiętego $\mathrm{w}$ testamencie.

4 Ustawa z dnia 23 kwietnia 1964 r. - Kodeks cywilny, tekst jednolity: Dz. U. z 2019 r. poz. 1145 (dalej: K.c.).

5 Zob. wyrok SA w Poznaniu z dnia 14 października 2010 r., I ACa 717/2010, LEX nr 3971504 .

6 Ustawodawca wprowadził również inne instytucje powodujące ograniczenie zasady swobody testowania, które jednak dotyczą w szczególności czynności technicznych, $\mathrm{w}$ tym dotyczących formy. Powołanie do dziedziczenia może nastąpić jedynie w testamencie tj. formie określonej przepisami. Spadkodawca nie może również dowolnie kształtować treści testamentu. Otóż w ramach testamentu niedopuszczalne jest powoływanie do konkretnych przedmiotów wchodzących w skład spadku, jak również podstawienie powiernicze, czy też powołanie do spadku pod warunkiem lub z zastrzeżeniem terminu. 
lacjach rodzinnych nakłada na spadkodawcę (za jego życia) szereg obowiązków rodzinnych, w tym obowiązek alimentacyjny. Naturalną konsekwencją relacji rodzinnych jest pragnienie osób najbliższych do udziału w spadku po zmarłej osobie bliskiej. Jednakże spadkodawcy często pomijają $\mathrm{w}$ testamencie osoby najbliższe lub niektóre $\mathrm{z}$ nich przekazując cały majątek osobom spoza grona osób najbliższych lub ustanawiają spadkobiercą tylko jedną z kilku osób najbliższych. Ważyć należy, że w granicach swobody testowania pozostają rozporządzenia spadkodawcy, które należałoby ocenić obiektywnie za nierozsądne lub niesprawiedliwe ${ }^{7}$. Ustawodawca mając na uwadze interesy osób najbliższych przyznaje im prawo do zachowku, które odpowiada równowartości 1/2 albo 2/3 udziału spadkowego, który by mu przypadł przy dziedziczeniu ustawowym. Jednocześnie ustawodawca zawęził krąg osób uprawnionych do zachowku do zstępnych, małżonka oraz rodziców spadkodawcy.

Szczególnie istotnym przy ustalaniu wysokości należnego uprawnionemu zachowku jest instytucja doliczenia darowizn oraz zapisów windykacyjnych do czynnego stanu spadku uregulowana w przepisach art. 993 i nast. K.c. Przedmiotem niniejszego opracowania jest jednak problem doliczenia darowizn. Zachowek zabezpiecza interes dzieci, małżonka oraz rodziców spadkodawcy przed niekorzystnym rozporządzeniem mieniem dokonywanym przez spadkodawcę. Z punktu widzenia uprawnionego bez znaczenia jest czy spadkodawca przekazał majątek $\mathrm{w}$ testamencie, czy darował określone składniki majątku na rzecz osób, które często są również spadkobiercami testamentowymi lub ustawowymi. Doliczenie darowizn do substratu zachowku jest możliwe, nawet gdy czynna wartość spadku jest zerowa lub ujemna. W takiej sytuacji zachowek będzie uzależniony właśnie od doliczenia darowizny ${ }^{8}$. Podstawą do obliczenia zachowku jest tzw. substrat zachowku, który stanowi czystą wartość spadku powiększoną o zapisy windykacyjne oraz darowizny podlegające

Do dnia 28 lipca 1990 r. ustawodawca przewidywał również ograniczenia swobody testowania $\mathrm{w}$ odniesieniu do gospodarstw rolnych i wkładów gruntowych $\mathrm{w}$ rolniczych spółdzielniach produkcyjnych. Swobodę testowania ograniczają również przepisy ustawy z dnia 24 marca 1920 r. o nabywaniu nieruchomości przez cudzoziemców (tekst jednolity: Dz. U. z 2017 r. poz. 2278). W doktrynie można jednak spotkać odmienne stanowisko, w myśl którego instytucja zachowku nie stanowi ograniczenia swobody testowania, zob. E. Skowrońska-Bocian, Testament w prawie polskim, Warszawa 2004, s. 127.

7 Zob. P. Księżak, Zachowek w polskim prawie spadkowym, Warszawa 2012, s. 23.

8 Zob. wyrok SN z dnia 7 lipca 1964 r., I CR 691/63, LEX nr 238. 
zaliczeniu zgodnie z zasadami określonymi w przepisie art. 993 i nast. K.c. Brak doliczenia do substratu zachowku darowizn umożliwiałby w łatwy sposób obejście przepisów o zachowku, co skutkowałoby tym, że ochrona osób najbliższych byłaby iluzoryczna. Spadkodawca nie może w testamencie wyłączyć zaliczenia na substrat zachowku wszystkich lub niektórych darowizn, albowiem skutkowałoby to unicestwieniem możliwości realizacji roszczenia o zachowek ${ }^{9}$. Jedyną formą ograniczenia lub wyłączenia prawa do zachowku jest wydziedziczenie, które może nastąpić w testamencie z przyczyn określonych w przepisie art. 1008 K.c., które muszą występować rzeczywiście.

Zagadnienie doliczenia do substratu zachowku darowizn rodzi wiele wątpliwości praktycznych, w szczególności w zakresie ustalenia granic pojęcia darowizny $w$ rozumieniu przepisu art. 993 K.c. Przy powierzchownej analizie wydawać się może, że podniesiony problem nie występuje, albowiem umowa darowizny jest umową nazwaną regulowaną przepisami art. 888 i nast. K.c., w myśl którego przez umowę darowizny darczyńca zobowiązuje się do bezpłatnego świadczenia na rzecz obdarowanego kosztem swego majątku. Wątpliwości budzi czy pojęcie darowizny na gruncie przepisu art. 993 K.c. odpowiada definicji legalnej umowy darowizny określonej w przepisie art. 888 K.c., czy też chodzić może również o inne przysporzenia o charakterze nieodpłatnym. Problematyka poruszana w niniejszym opracowaniu była już wielokrotnie przedmiotem rozważań przedstawicieli doktryny, jednakże z uwagi na powszechność zjawiska polegającego na przenoszeniu majątku w celu pokrzywdzenia przynajmniej jednego ze spadkobierców, wymaga dodatkowej analizy. Nadto w dotychczasowych opracowaniach brak jest wyczerpującej analizy - z punktu widzenia zaliczenia do substratu zachowku - takich zdarzeń prawnych jak rozszerzenie ustawowej wspólności majątkowej małżeńskiej na majątek nabyty przez jednego z małżonków przed zawarciem małżeństwa, sprzedaż poniżej wartości rynkowej, zamiana, zaniechanie dochodzenia zwrotu pożyczki, obdarowanie bez zachowania formy aktu notarialnego. $\mathrm{W}$ doktrynie wyrażono na ten temat wiele poglądów: od przyjęcia, że za darowiznę w kontekście art. 933 K.c. należy przyjąć

9 Jedynie na marginesie podnoszę, że przepis art. 1039 § 1 K.c. przewiduje możliwość zwolnienia poszczególnych darowizn lub zapisów windykacyjnych od zaliczenia na schedę spadkową, co jednak nie może wywoływać skutku w postaci zwolnienia z zaliczenia na poczet substratu zachowku i nie ma jakiegokolwiek wpływu na jego wysokość. 
wyłącznie darowiznę w rozumieniu przepisu art. 888 K.c., aż po pogląd, że chodzi o wszelkie świadczenia nieodpłatne. Odpowiedź na przedstawiony problem winna zostać udzielona w kontekście celu, dla jakiego została powołana instytucja zachowku, którym jest zabezpieczenie interesów majątkowych najbliższych członków rodziny spadkodawcy, przy czym katalog ten został ograniczony wyłącznie do dzieci oraz małżonka spadkodawcy. Do zachowku nie są uprawnieni zatem rodzice oraz rodzeństwo spadkodawcy. Odwołanie się wyłącznie do wykładni literalnej powołanego przepisu mogłoby prowadzić do wypaczenia celu instytucji zachowku. Dla uprawnionego do zachowku obojętnym jest pod jakim formalnym tytułem prawnym spadkodawca pozbędzie się majątku przed otwarciem spadku. Nie sposób wykluczyć, że spadkodawca w formie innych czynności prawnych niż darowizna dokona przeniesienia za życia całości lub części swojego majątku (np. podział majątku wspólnego bez obowiązku spłaty, rozszerzenie wspólności majątkowej małżeńskiej itp.), co skutkowałyby faktyczną bezskutecznością lub ograniczeniem roszczenia o zachowek. Przy wykładni pojęcia darowizny na potrzeby zaliczenia danego świadczenia do substratu zachowku nie można stracić z pola widzenia, że niektóre instytucje prawa cywilnego, których skutkiem jest nieodpłatne przysporzenie z majątku spadkodawcy na rzecz osoby trzeciej, wykształciły się długo po powstaniu K.c. Doliczenie darowizny do spadku zapobiega prostemu obejściu przepisów o zachowku. Przesądzające znaczenie winien mieć skutek czynności prawnej spadkodawcy, a nie jej typ. Dla uprawnionego istotnym jest bowiem czy po śmierci spadkodawcy pozostanie substrat zachowku stanowiący podstawę do obliczenia należnego świadczenia. Jako irrelewantny uznać należy natomiast cel działania dokonującego czynności prawnej, bowiem po jego śmierci ustalenie tego celu może okazać się niemożliwe. Nadto cel działania, chociażby najbardziej szczytny, nie powinien ograniczać uprawnień najbliższej rodziny do części majątku po zmarłym należnej w ramach zachowku.

Przyjąć należy, że do substratu zachowku winny zostać doliczone wszystkie rozporządzenia spadkodawcy na rzecz osób trzecich dokonane causa donandi skutkujące zubożeniem majątku spadkowego niezależnie od ich formy prawnej (np. darowizna, rozszerzenie wspólności majątkowej małżeńskiej, dyspozycja wkładem bankowym na wypadek śmierci, dyspozycja członka funduszu inwestycyjnego otwartego, dyspozycja wkładem członkowskim i oszczędnościowym w spółdzielczej kasie oszczędnościowo-kredytowej, dyspozycja środkami zgromadzonymi w funduszu 
emerytalnym, dyspozycja udziałami w spółdzielni, dyspozycja składkami na życie, umowa z następcą, nieodpłatne zniesienie współwłasności, zrzeczenie się roszczenia). Z kolei w sytuacji, gdy umowa ma charakter mieszany: częściowo odpłatny, częściowo nieodpłatny (negotium mixtum cum donatione), zaliczeniu powinna podlegać ta część, która nie znajduje ekwiwalentu w świadczeniu drugiej strony ${ }^{10}$. Zaznaczenia wymaga, że chodzi wyłącznie o czynności prawne skutkujące uszczerbkiem w majątku spadkodawcy, a nie o czynności prawne lub tym bardziej faktyczne skutkujące brakiem wzrostu aktywów spadku. Jednocześnie zaliczeniu podlegają te czynności, które skutkują wzrostem w majątku obdarowanego, a nie te, które skutkują jedynie brakiem wydatków z tego majątku. Nie podlegają zatem zaliczeniu czynności faktyczne (jak pomoc przy budowie domu) czy czynności prawne (jak użyczenie sprzętu budowlanego).

Nie sposób abstrakcyjnie wskazać wszystkie czynności, które można zakwalifikować jako darowizny na potrzeby ustalenia substratu zachowku. Ustalenie czy daną czynność należy zakwalifikować jako darowiznę w rozumieniu art. 993 K.c. należy każdorazowo do sądu w konkretnej sprawie $\mathrm{w}$ przedmiocie zasądzenia świadczenia pieniężnego $\mathrm{z}$ tytułu zachowku. Za nadal aktualny należy uznać wyrok Sądu Najwyższego (SN) z dnia 17 czerwca 1953 r., w myśl którego odrębne powództwo o ustalenie jest niedopuszczalne $\mathrm{z}$ uwagi na brak interesu prawnego ${ }^{11}$.

Jedną z czynności prawnych, które niewątpliwie należy uznać za darowizny $\mathrm{w}$ rozumieniu przepisu art. 993 K.c., jest zniesienie współwłasności bez obowiązku spłaty lub dopłaty. Sąd Najwyższy w wyroku z dnia 19 marca 2009 r. stwierdził, że umowa obligacyjna obejmująca zniesienie między współwłaścicielami współwłasności nieruchomości w wyniku nieodpłatnego przeniesienia przez jednego z nich udziałów we współwłasności na drugiego, dotychczasowego współwłaściciela, może być kwalifikowana jako umowa darowizny i w związku z tym należy do niej stosować także przepisy o możliwości odwołania darowizny już wykonanej (art. 898 § 1 K.c.) $)^{12}$. Mowa przede wszystkim o umownym zniesieniu

10 Zob. K.P. Sokołowski, Forma aktu notarialnego, uzupetnienie zachowku oraz ustalenie schedy spadkowej a "negotium mixtum cum donatione", Rejent 2011, nr 7/8, s. 134.

11 Zob. wyrok SN z dnia 17 czerwca 1953 r., II C 534/53, LEX nr 117618. Brak interesu prawnego wynika z faktu, że uprawniony może wytoczyć powództwo dalej idące o zapłatę.

12 Zob. wyrok SN z dnia 19 marca 2009 r., III CSK 307/08, LEX nr 492154. Podobnie Sąd Apelacyjny we Wrocławiu w wyroku z dnia 25 sierpnia 2009 r., I ACa 455/2009, LEX nr 2082380. 
współwłasności, w tym również w drodze ugody zawartej przed sądem, bowiem w przypadku sądowego zniesienia współwłasności sąd co do zasady będzie zasądzał na rzecz niektórych uczestników odpowiednie spłaty lub dopłaty. Nie można jednak wykluczyć, że uczestnicy będą wnioskowali o zniesienie współwłasności poprzez np. przeniesienie własności całości nieruchomości na rzecz jednego z nich bez obowiązku spłaty. Sąd zgodnie z przepisem art. 321 Kodeksu postępowania cywilnego ${ }^{13}$ $\mathrm{W}$ ZW. $\mathrm{z}$ art. 13 § 2 K.p.c. jest związany granicami wniosku i nie powinien zgodnie z zasadą dyspozycyjności oraz kontradyktoryjności wychodzić ponad żądanie uczestników ${ }^{14}$, w szczególności w sytuacji, gdy uczestnicy wyraźnie oświadczą, że nie żądaj spłaty. Forma zniesienia współwłasności nie ma zatem znaczenia. Na analogicznych zasadach za darowizny należy uznać nieodpłatne zniesienie majątku wspólnego po ustaniu małżeństwa oraz stosunku spółki cywilnej, jeżeli jeden z małżonków albo wspólnik oświadczają o zrzeczeniu się należnej mu spłaty. Powyższe szeroko omawiane $\mathrm{w}$ doktrynie oraz orzecznictwie i akceptowane poglądy należy uzupełnić poprzez wskazanie, że w razie dokonania zniesienia współwłasności, w ramach której dokonywana jest spłata, jednakże w niższej wysokości niż to wynika z liczby lub wartości udziałów we współwłasności, to wartość rzeczy przyznawanej na wyłączną własność jednemu ze współwłaścicieli, która nie znajduje ekwiwalentu w spłacie, powinna zostać uznana za darowiznę zaliczaną do ustalenia substratu zachowku. Jeżeli nieruchomość o wartości 120000 zł stanowiła współwłasność w częściach równych pomiędzy matką i córką, które dokonały zniesienia współwłasności w taki sposób, że córka stała się właścicielem całości nieruchomości z obowiązkiem spłaty na rzecz matki w kwocie 20000 zł, to wówczas na potrzeby zachowku należałoby uznać, że matka darowała córce $40000 \mathrm{zl}$, ponieważ według udziałów oraz wartości nieruchomości matce przysługiwała spłata w kwocie $60000 \mathrm{zł}$.

Darowizną na potrzeby ustalenia wysokości zachowku jest również sprzedaż rzeczy lub prawa majątkowego za cenę poniżej wartości rynkowej, jeżeli różnica jest rażąca, przy czym za darowiznę uznać należy różnicę pomiędzy ceną sprzedaży a wartością rynkową. Nie każda sprzedaż poniżej wartości rynkowej może być traktowana jako częściowa

13 Ustawa z dnia 17 listopada 1964 r. - Kodeks postępowania cywilnego, tekst jednolity: Dz. U. z 2019 r. poz. 1460 z późn. zm. (dalej: K.p.c.).

14 Zob. też wyrok SN z dnia 25 czerwca 2015 r., V CSK 612/14, LEX nr 1771393. 
darowizna (w zakresie różnicy pomiędzy ceną sprzedaży a wartością rynkową), a jedynie, jeżeli cena sprzedaży rażąco odbiega od wartości rynkowej. Na uwadze należy mieć bowiem przepis art. 3531 K.c., w myśl którego strony mogą ułożyć stosunek prawny według swojego uznania, byleby jego treść lub cel nie był sprzeczny z właściwością stosunku, ustawą lub zasadami współżycia społecznego. O tym czy różnica jest rażąca, czy też nie, decydować powinien sąd na podstawie okoliczności danego przypadku, w szczególności w oparciu o dowód z opinii biegłego rzeczoznawcy. Należy mieć na uwadze, że naturalnym celem umowy sprzedaży jest przeniesienie prawa własności za cenę odpowiadającą wartości rynkowej. Sprzedający uzyskuje ekwiwalent $\mathrm{w}$ postaci równowartości przenoszonej rzeczy lub prawa. W razie rażącej różnicy pomiędzy wartością rynkową przedmiotu sprzedaży a umówioną ceną trudno traktować umowę nadal, jako umowę sprzedaży mając na uwadze przepis art. 65 K.c. oraz art. 58 K.c. W innym wypadku spadkodawca mógłby w prosty sposób wyeliminować zastosowanie przepisu art. 993 K.c. Nie sposób uznać za umowę sprzedaży w całości umowy, której treścią sprzedający przenosi na własność kupującego nieruchomość wartą 1000000 zł za cenę 10000 zł. Dysproporcja pomiędzy wartością nieruchomości a ceną sprzedaży jest bowiem rażąca. Umowę taką na potrzeby zachowku należy poczytać - przy uwzględnieniu proporcji pomiędzy ceną sprzedaży a wartością rynkową - za umowę sprzedaży w zakresie udziału wynoszącego 1/100, a $\mathrm{w}$ pozostałym zakresie - jako umowę darowizny. Umówiona cena sprzedaży odpowiada bowiem wartości udziału wynoszącego 1/100. Podobnie będzie w przypadku umowy zamiany. Jeżeli rodzice zamienią się z dzieckiem w taki sposób, że dziecko otrzyma dom o wartości znacznie przekraczającej wartość otrzymanego w zamian mieszkania. Wówczas za darowiznę należy uznać różnicę pomiędzy wartością rynkową domu a wartością mieszkania.

Za darowizny na potrzeby ustalenia wysokości zachowku należy również uznać dyspozycje prawami majątkowymi na wypadek śmierci dokonane na podstawie przepisów odrębnych: dyspozycję wkładem bankowym na wypadek śmierci ${ }^{15}$, dyspozycję wkładem członkowskim

15 Zgodnie z art. 56 ust. 1 ustawy - Prawo bankowe posiadacz rachunku lub lokaty może pisemnie polecić bankowi dokonanie - po swojej śmierci - wypłaty z rachunku wskazanym przez siebie osobom: małżonkowi, wstępnym, zstępnym lub rodzeństwu określonej kwoty pieniężnej, przy czym kwota ta nie może przekraczać dwudziestokrotności 
i oszczędnościami w SKOK ${ }^{16}$, dyspozycję uczestnika otwartego funduszu emerytalnego ${ }^{17}$, dyspozycję środkami zgromadzonymi w funduszu emerytalnym ${ }^{18}$. Cechą wspólną wskazanych instytucji jest możliwość przeniesienia mortis causa określonego świadczenia na rzecz określonych osób z wyłączeniem przenoszonego świadczenia z dziedziczenia po rozporządzającym. Przedmiot dyspozycji nie wchodzi w skład spadku. Szczególnie należy podkreślić, iż z punktu widzenia beneficjenta dyspozycji zachodzi skutek identyczny jak w przypadku darowizny, w szczególności dyspozycje mają charakter nieodpłatny.

W niektórych sytuacjach za darowiznę może być uznane rozszerzenie ustawowej wspólności majątkowej małżeńskiej. Powyższy problem nie jest jednak jednoznaczny. W doktrynie można znaleźć kategoryczne stanowisko aprobujące $w$ tym zakresie ${ }^{19}$. $Z$ tak kategorycznym stanowiskiem nie sposób jednak się zgodzić. Nie można bowiem stracić z pola widzenia

przeciętnego miesięcznego wynagrodzenia w sektorze przedsiębiorstw bez wypłat nagród z zysku, ogłaszane przez Prezesa Głównego Urzędu Statystycznego za ostatni miesiąc przed śmiercią posiadacza rachunku.

16 Zgodnie z art. 14 ust. 1 pkt 2 ustawy z dnia 5 listopada 2009 r. o spółdzielczych kasach oszczędnościowo-kredytowych (tekst jednolity: Dz. U. z 2019 r. poz. 2412 z późn. zm.) kasa zobowiązana jest wypłacić po śmierci członka kasy z jego wkładu członkowskiego i oszczędności kwotę nieprzekraczającą ogółem sumy przeciętnego miesięcznego wynagrodzenia w gospodarce narodowej, ogłaszanej przez Prezesa Głównego Urzędu Statystycznego, w okresie 5 lat kalendarzowych poprzedzających wypłatę - jeżeli członek kasy pisemnie wskazał kasie osoby, na których rzecz wypłata ma nastąpić; osobami wskazanymi przez członka kasy mogą być jego małżonek, zstępni, rodzice, dziadkowie i rodzeństwo.

17 Zgodnie z art. 111 ust. 1 pkt 2 ustawy z dnia 27 maja 2004 r. o funduszach inwestycyjnych i zarządzaniu alternatywnymi funduszami inwestycyjnymi (tekst jednolity: Dz. U. z 2020 r. poz. 95) w razie śmierci uczestnika funduszu inwestycyjnego otwartego, fundusz zobowiązany jest na żądanie osoby, którą uczestnik wskazał funduszowi w pisemnej dyspozycji - odkupić jednostki uczestnictwa uczestnika zapisane w rejestrze uczestników funduszu do wartości nie wyższej niż przypadające na ostatni miesiąc przed śmiercią uczestnika funduszu dwudziestokrotne przeciętne miesięczne wynagrodzenie w sektorze przedsiębiorstw bez wypłat nagród z zysku, ogłaszane przez Prezesa Głównego Urzędu Statystycznego, oraz nieprzekraczającej łącznej wartości jednostek uczestnictwa zapisanych w rejestrze uczestnika, oraz wypłacić tej osobie kwotę uzyskaną z tego odkupienia.

18 Zgodnie z art. 132 ust. 1 ustawy z dnia 28 sierpnia 1997 r. o organizacji i funkcjonowaniu funduszy emerytalnych (tekst jednolity: Dz. U. z 2020 r. poz. 105) środki zgromadzone na rachunku zmarłego członka otwartego funduszu emerytalnego, które nie zostaną wykorzystane zgodnie z art. 131, przekazywane są osobom wskazanym przez zmarłego, zgodnie z art. 82 ust. 1 lub 1a, a w przypadku ich braku wchodzą w skład spadku.

19 Zob. w szczególności P. Księżak, Zachowek w polskim prawie..., s. 302. 
faktu, że małżonkowie mają prawo do kształtowania ustroju majątkowego w małżeństwie za pomocą umów majątkowych małżeńskich. Nie każda jednak ingerencja w stosunki majątkowe w małżeństwie może być uznana za umowę majątkową małżeńską. Nie każda umowa, chociażby określona przez strony jako umowa majątkowa, będzie miała taki charakter. Istotne są bowiem essentialia negoti umowy, a nie jej oznaczenie przez strony. Celem małżeńskiej umowy majątkowej jest ustalenie zasad, według których kształtować się mają wzajemne stosunki majątkowe małżonków, a więc uregulowanie istnienia i zakresu wspólności ustawowej. Umowy o rozszerzenie wspólności ustawowej w zakresie, w jakim ustanawiają zasadę kształtującą ustrój majątkowy, a więc są stricte umowami majątkowymi małżeńskimi, działają na przyszłość i mają charakter organizacyjny ${ }^{20}$. Uznać zatem należy, że takich skutków nie powoduje rozporządzenie dotyczące konkretnego, indywidualnie oznaczonego przedmiotu majątku osobistego, który z woli małżonków ma wejść do majątku wspólnego, ewentualnie wolą stron ma zostać przeniesiony z majątku wspólnego do majątku osobistego ${ }^{21}$. Niewątpliwie za darowiznę na gruncie zachowku należy uznać umowę majątkową małżeńską rozszerzającą majątek wspólny o majątek posiadany przez strony umowy przed zawarciem małżeństwa, jeżeli dysproporcja pomiędzy tymi majątkami jest rażąca, a tym bardziej, jeżeli tylko jeden z małżonków posiadał aktywa. Przykładowo: w dacie zawarcia umowy majątkowej rozszerzającej wspólność jeden z małżonków pozostaje bez pracy, nie posiada jakiegokolwiek majątku za wyjątkiem rzeczy o charakterze osobistym, natomiast drugi z małżonków jest właścicielem kilku nieruchomości. W powołanej sytuacji celem stron jest niewątpliwie bezpłatne przysporzenie, a nie organizacja ustroju majątkowego i jego składników.

Małżonkowie mają również możliwość przenoszenia praw z majątku wspólnego do majątku odrębnego w czasie trwania ustawowej wspólności

20 Zob. wyrok SA w Łodzi z dnia 7 sierpnia 2015 r., I ACa 185/15, LEX nr 1808658.

21 Sąd Najwyższy w wyroku z dnia 25 listopada 2003 r. (II CK 273/02, LEX nr 424449) wypowiedział się w analogicznym kontekście w odniesieniu do skutków rozporządzenia konkretnym, indywidualnie oznaczonym przedmiotem z majątku wspólnego do majątku odrębnego małżonków. Podobnie należy rozumieć uchwałę 7 sędziów SN z dnia 10 kwietnia 1991 r. (III CZP 76/90, LEX nr 3659). Pewne wątpliwości może budzić teza wyroku Sądu Apelacyjnego w Łodzi z dnia 18 lipca 2013 r. (I ACa 244/13, LEX nr 1353761), zgodnie z którą umowa rozszerzająca ustawową wspólność majątkową małżeńską nie może wywrzeć skutków prawnych przewidzianych w art. 99 K.c. dla umowy darowizny. 
majątkowej małżeńskiej ${ }^{22}$. W tym przypadku przeniesienie praw następuje jednak w ramach umów o charakterze rozporządzającym, a w szczególności darowizny, sprzedaży czy zamiany, a nie w ramach umowy majątkowej małżeńskiej, bowiem celem umowy majątkowej małżeńskiej jest ustalenie zasad, według których kształtować będą się wzajemne stosunki małżonków, a więc uregulowanie istnienia i zakresu wspólności ustawowej. Takich skutków nie powoduje natomiast rozporządzenie dotyczące konkretnego, indywidualnie oznaczonego przedmiotu majątku wspólnego, który z woli stron ma wyjść z majątku wspólnego i wejść do majątku osobistego jednego $\mathrm{z}$ małżonkó $\mathrm{w}^{23}$. W razie dokonania darowizny $\mathrm{z}$ majątku wspólnego do majątku osobistego jednego z małżonków, darowizna taka powinna być uwzględniona przy obliczaniu zachowku.

Szczególny problem podczas analizy problematyki ujawnia się przy ocenie umowy z następcą określonej w art. 84-91 ustawy z dnia 20 grudnia 1990 r. o ubezpieczeniu społecznym rolników ${ }^{24}$. Charakter prawny umowy w nauce oraz orzecznictwie budził wątpliwości, jednakże w ostatnim okresie przeważa pogląd, że umowa z następcą nie stanowi umowy darowizny w rozumieniu przepisu art. 888 K.c., nawet wówczas, gdy gospodarstwo rolne jest przenoszone nieodpłatnie na następcę ${ }^{25}$. Uznać należy, że umowa z następcą stanowi odrębną umowę nazwaną, co wynika wprost z przepisów powołanej ustaw ${ }^{26}$. Powstaje pytanie czy nieodpłatne przeniesienie nieruchomości na następcę stanowi podstawę do zaliczenia wartości przeniesionej nieruchomości na substrat zachowku. $W$ tym

22 Zob. uchwała 7 sędziów SN z dnia 10 kwietnia 1991 r., III CZP 76/90.

${ }^{23}$ Zob. wyrok SN z dnia 25 listopada 2003 r., II CK 273/02, LEX nr 424449.

24 Ustawa z dnia 20 grudnia 1990 r. o ubezpieczeniu społecznym rolników, tekst jednolity: Dz. U. 2020 r. poz. 174. Przez umowę z następcą rolnik będący właścicielem (współwłaścicielem) gospodarstwa rolnego zobowiązuje się przenieść na osobę młodszą od niego co najmniej o 15 lat (następcę) własność (udział we współwłasności) i posiadanie tego gospodarstwa z chwilą nabycia prawa do emerytury lub renty inwalidzkiej, jeżeli następca do tego czasu będzie pracować w tym gospodarstwie. Ponadto umowa z następcą może zawierać inne postanowienia, w szczególności dotyczące wzajemnych świadczeń stron przed i po przeniesieniu przez rolnika własności gospodarstwa rolnego na następcę.

25 Zob. E. Drozd, Podstawowe zagadnienia konstrukcyjne umowy z następca, Rejent 1991, nr 3, s. 17; R. Pastuszko, Umowa przekazania gospodarstwa rolnego następcy jako podstawa wpisu w księdze wieczystej, Rejent 2004, nr 9, s. 48.

26 Zob. w szczególności J. Durka, Przekazywanie gospodarstw rolnych następcy na podstawie przepisów ustawy o zaopatrzeniu emerytalnym i innych świadczeniach dla rolników $i$ ich rodzin, Nowe Prawo 1978, nr 11/12, s. 1635. 
kontekście wypowiedział się Sąd Najwyższy w uchwale z dnia 19 lutego 1991 r., (III CZP 4/91) wskazując, że wartości gospodarstwa rolnego przekazanego nieodpłatnie następcy nie uwzględnia się przy ustaleniu zachowku ${ }^{27}$. Stanowisko SN w doktrynie zostało poddane krytyce ${ }^{28}$. Mimo tych krytycznych uwag, SN uchwałą z dnia 21 czerwca 2012 r. (III CZP 29/12) podtrzymał swój dotychczasowy pogląd w sprawie ${ }^{29}$. Ze stanowiskiem SN nie sposób się zgodzić. Umowa z następcą zawiera elementy prawa ubezpieczeń społecznych, administracyjnego oraz cywilnego. W nieodpłatnej umowie przekazania gospodarstwa rolnego causa donandi jest oczywista. Nie sposób pominąć, że gospodarstwo rolne zazwyczaj jest jedynym składnikiem majątku przekazującego, a zatem pozostali członkowie rodziny, nawet $\mathrm{w}$ przypadku powołania do spadku, nie otrzymaliby jakiegokolwiek przysporzenia. Taka sytuacja jest nie do pogodzenia z zasadami słuszności oraz sprawiedliwości społecznej i całkowicie udaremnia cel instytucji zachowku. Brak przy tym argumentów do przyjęcia, że szczególny charakter tej umowy daje podstawy do wyeliminowania ochrony osób najbliższych spadkodawcy.

Należałoby się zastanowić czy za darowiznę na potrzeby ustalenia zachowku powinno się uznać jedynie przysporzenia wynikające z działania, czy też chodzić może również o wzbogacenie będące skutkiem zaniechania. W konsekwencji zastanowić siętrzeba czy do uznania danego zdarzenia za darowiznę niezbędne jest złożenie oświadczenia woli. Przyjąć należy, że za darowiznę w niektórych sytuacjach winno się również uznać nie tylko czynności wynikające z działania, ale również z zaniechania lub zdziałane w sposób niesformalizowany. Darowizną niewątpliwie będzie udzielenie pożyczki, jeżeli następnie uprawniony zrzekł się roszczenia o zwrot pożyczki, przy czym w tym przypadku mamy do czynienia z działaniem pożyczkodawcy oraz ze złożeniem wyraźnego oświadczenia woli. Przytoczona sytuacja występuje bardzo często w stosunkach rodzinnych w szczególności wstępni często pożyczają zstępnym pieniądze, np. na zakup nieruchomości, samochodu lub na zaspokojenie bieżących potrzeb, po czym oświadczają, że nie oczekują zwrotu pożyczonych środków.

27 Uchwała SN z dnia 19 lutego 1991 r., III CZP 4/91, LEX nr 520097345.

28 Zob. A. Szpunar, Uwagi o obliczaniu wysokości zachowku, Rejent 2002, nr 4, s. 26; L. Stecki, Darowizna, Torun 1998, s. 313; E. Niezbecka, w: Kodeks cywilny. Komentarz, t. 4. Spadki, red. A. Kidyba, Warszawa 2008, s. 185; P. Księżak, Zachowek w polskim prawie..., s. 298.

29 Uchwała SN z dnia 21 czerwca 2012 r., III CZP 29/12, LEX nr 521335790. 
Za darowiznę należy uznać również zaniechanie pożyczkodawcy prowadzące do przedawnienia się wierzytelności z tytułu udzielonej pożyczki, jeżeli z okoliczności wynika, że zwłoka w dochodzeniu roszczenia była celowa, a pożyczkodawca chciał bezpłatnie uposażyć pożyczającego. W tej sytuacji nie mamy jednak do czynienia ze złożeniem oświadczenia woli. Zwłoka w dochodzeniu zwrotu pożyczki nie stanowi oświadczenia woli. Uznać zatem należy, że - co do zasady - darowizna na gruncie przepisu art. 993 K.c. będzie wynikała z oświadczenia woli, jednakże nie zawsze oświadczenie woli nie jest warunkiem koniecznym uznania niektórych zdarzeń za darowizny w rozumieniu powołanego przepisu (w odróżnieniu od darowizny z art. 888 K.c.). Podzielić należy pogląd L. Steckiego, który uważa, że za darowiznę należy również uznać przekazanie własności nieruchomości bez zachowania formy aktu notarialnego, jeżeli doszło następnie do nabycia prawa własności w drodze zasiedzenia ${ }^{30}$. Analogicznie należy rozwiązać problem nabycia nieruchomości przez posiadaczy na podstawie przepisów ustawy z dnia 26 października 1971 r. o uregulowaniu własności gospodarstw rolnych ${ }^{31}$. Darowizna dokonana z naruszeniem formy aktu notarialnego, która stała się podstawą uwłaszczenia na podstawie przepisów powołanej ustawy, niewątpliwie zalicza się do katalogu darowizn, o których mowa w przepisie art. 993 K.c. Celem ustawodawcy było bowiem usunięcie niepewności prawnej związanej z obrotem nieruchomościami w stosunkach wiejskich przed wejściem w życie ustawy, a nie wyłączenie tych darowizn z katalogu darowizn zaliczanych na zachowek. Pierwotny charakter nabycia nieruchomości w drodze zasiedzenia lub uwłaszczenia nie powinien mieć jakiegokolwiek znaczenia dla rozstrzygnięcia możliwości zaliczenia tych zdarzeń prawnych jako darowizny w rozumieniu przepisu art. 993 K.c.

Samo ustalenie substratu zachowku jest czynnością rachunkową. Doliczenie darowizny do substratu zachowku nie skutkuje jakimikolwiek

30 Zob. L. Stecki, Darowizna, s. 314.

31 Zgodnie z art.1 ust. 1 ustawy z dnia 26 października 1971 r. o uregulowaniu własności gospodarstw rolnych (Dz. U. z 1971 r. Nr 27, poz. 250 z późn. zm.) nieruchomości wchodzące $\mathrm{w}$ skład gospodarstw rolnych znajdujące się $\mathrm{w}$ dniu wejścia $\mathrm{w}$ życie ustawy (4 listopad 1971 r.) w samoistnym posiadaniu rolników stają się z mocy prawa własnością rolników, jeżeli oni sami lub ich poprzednicy prawni objęli te nieruchomości w posiadanie na podstawie zawartych bez przewidzianej prawem formy umowy sprzedaży, zamiany, darowizny, dożywocia lub innej umowy o przeniesienie własności, zniesienie współwłasności albo dział spadku. 
zmianami w przedmiocie własności darowanej nieruchomości. Od aktywów spadku odlicza się długi spadkowe, a następnie dolicza się darowizny w rozumieniu przepisu art. 993 K.c. uczynione przez spadkodawce oraz zapisy windykacyjne. Od wartości aktywów spadku nie odlicza się jednak zapisów zwykłych oraz poleceń, chociaż są długami spadkowymi. Doliczeniu podlegają wyłącznie darowizny uczynione przez spadkodawcę, zatem a contrario doliczeniu nie będą podlegały darowizny uczynione przez inne osoby, w tym małżonka spadkodawcy, nawet wówczas, gdy pozostawał ze spadkodawcą w ustroju wspólności majątkowej małżeńskiej, z tym zastrzeżeniem, że przedmiot darowizny wchodził do majątku osobistego małżonka spadkodawcy. Powyższa sytuacja będzie aktualna nawet wtedy, gdy darczyńca był uprzednio obdarowany przez spadkodawcę. $\mathrm{W}$ razie dokonania darowizny przez małżonków z majątku wspólnego, doliczeniu do zachowku podlega wyłącznie połowa wartości przedmiotu darowizny ${ }^{32}$. Przy czym $\mathrm{w}$ doktrynie podnosi się, że $\mathrm{w}$ razie ustalenia przez sąd nierównego udziału w majątku wspólnym, doliczeniu do substratu zachowku powinna podlegać wartość darowizny obliczona przy uwzględnieniu tego udziału ${ }^{33}$. Zgodzić należy się z poglądem A. Szpunara, że do substratu zachowku dolicza się również darowizny, które zostały wykonane dopiero po śmierci spadkodawcy. Rozstrzygające znaczenie ma wówczas data czynności prawnej, a nie jej faktyczne wykonanie $^{34}$. W razie obciążenia darowizny poleceniem, do substratu zachowku doliczeniu podlega wyłącznie czysta wartość darowizny, tj. darowizna pomniejszona o wartość świadczeń, którymi został obciążony obdarowany. Darowizna doliczana do substratu zachowku podlega również obniżeniu o wartość obciążeń uczynionych na rzeczy darowanej. Najczęściej spotykanym w praktyce obciążeniem nieruchomości jest ustanowienie na rzecz darczyńcy osobistej, dożywotnej służebności mieszkania ${ }^{35}$.

Ustawodawca w art. 994 K.c. przewidział również katalog darowizn, które nie podlegają doliczeniu do substratu zachowku. Katalog ten ma charakter numerus clausus. Po pierwsze, przy obliczaniu zachowku nie dolicza się drobnych darowizn, zwyczajowo przyjętych $\mathrm{w}$ stosunkach

32 Zob. wyrok SN z dnia 12 maja 2000 r., II CKN 542/00, LEX nr 559927.

33 Zob. P. Księżak, Zachowek w polskim prawie..., s. 274.

34 Zob. A. Szpunar, Uwagi o prawie do zachowku, Rejent 2002, nr 6, s. 13.

35 Zob. wyrok SA w Katowicach z dnia 17 stycznia 2014 r., I ACa 972/13, LEX nr 1441392. 
danego rodzaju. Choć jak wskazano przepis art. 994 K.c. zawiera katalog zamknięty darowizn, które nie podlegają doliczeniu, to jednak pojęcie drobnych darowizn, zwyczajowo przyjętych ma charakter nieostry, co może rodzić trudności praktyczne, w szczególności co do ustalenia czy darowizna $\mathrm{w}$ danych stosunkach jest zwyczajowo przyjęta, a także czy darowizna ma charakter drobny, czy wykracza ponad tę miarę. Znaczenie przesądzające powinny mieć kryteria obiektywne odnoszące się zarówno do oceny czy darowizna ma charakter zwyczajowo przyjęty w stosunkach danego rodzaju, jak również w zakresie ustalenia czy darowiznę należy zakwalifikować jako drobną. Oba wyżej wymienione kryteria winny być oceniane łącznie, bowiem darowizna o jednakowej wartości w danych relacjach podmiotowych może zostać uznana za drobną, a w innych - już nie. Nie sposób bowiem pominąć relacji podmiotowych pomiędzy darczyńcą a obdarowanym ${ }^{36}$. Zwyczajowe darowizny związane są przede wszystkim z różnorodnymi uroczystościami rodzinnymi (chrzciny, imieniny, wesele), przy czym zwyczajowo akceptowalne są wyższe darowizny w związku z uroczystościami weselnymi niż np. z uroczystościami imieninowymi. Za kryterium kwalifikujące darowiznę do darowizn drobnych należy uznać wartość przedmiotu darowizny, a nie sytuację materialną spadkodawcy lub obdarowanego ${ }^{37}$. Za drobne darowizny zwyczajowo przyjęte w stosunkach danego rodzaju uznać należy darowizny społecznie akceptowane, zasługujące na aprobatę w społecznej ocenie dokonywanej przez obserwatora o przeciętnej sytuacji materialnej. Nie sposób byłoby uznać za drobne, w rozumieniu przepisu art. 994 K.c., darowizny o niewielkiej wartości dokonywane systematycznie w znacznej perspektywie czasowej. W tej sytuacji pod ocenę powinna być brana suma darowizn. Za darowiznę zwyczajowo przyjętą w stosunkach rodzinnych należałoby uznać jednorazową bądź nawet kilkukrotną darowiznę w niewielkiej

36 Tytułem przykładu można wskazać, że prezent ślubny uczyniony przez rodziców na rzecz małżonków o wartości przekraczającej nawet kilkukrotnie najniższe wynagrodzenie należałoby zakwalifikować jako drobną darowiznę zwyczajowo przyjętą w stosunkach tego rodzaju, jednakże darowiznę w tej samej wysokości uczynioną na rzecz małżonków przez pozostałych gości weselnych niespokrewnionych z małżonkami trudno byłoby zakwalifikować jako darowiznę drobną.

37 Zob. wyrok SA w Gdańsku z dnia 8 lipca 2015 r., V ACa 126/15, LEX nr 1842298. We wskazanym orzeczeniu sąd uznał, że darowizny dokonywane przez rodziców na rzecz dzieci celem uposażenia umożliwiającego usamodzielnienie się nie stanowią darowizn drobnych. 
wysokość przekazaną przez rodziców na rzecz jednego z dzieci celem pokrycia bieżących potrzeb żywnościowych rodziny z uwagi na utratę pracy. Nie sposób jednak uznać tego typu darowizn za drobne i zwyczajowo przyjęte, gdyby były dokonywane systematycznie na przestrzeni kilkunastu miesięcy, a tym bardziej lat. Wówczas suma darowizn powinna podlegać zaliczeniu do substratu zachowku.

Po drugie, nie podlegają doliczeniu darowizny dokonane przed więcej niż 10 laty, licząc wstecz od otwarcia spadku, dokonane na rzecz osób trzecich niebędących spadkobiercami albo uprawnionymi do zachowku. Niektórzy autorzy wskazują na pewne trudności przy wykładni tego przepisu związane z zawiłą stylistyką powołanego przepisu ${ }^{38}$, jednakże zawiłości te nie wywołują nadmiernych wątpliwości w orzecznictwie. Sąd Apelacyjny w Białymstoku w wyroku z dnia 12 listopada 1996 r. ${ }^{39}$ uznał, że wyłączenie zaliczenia darowizn po upływie 10 lat od otwarcia spadku dotyczy wyłącznie darowizn, które zostały zdziałane na rzecz osób obcych, niebędących ani spadkobiercami, ani uprawnionymi do zachowku. A zatem a contrario uznać należy, że podlegają zaliczeniu darowizny uczynione na rzecz spadkobiercy lub uprawnionych do zachowku niezależnie od daty ich dokonania, czyli również darowizny dokonane dawniej niż 10 lat przed śmiercią spadkodawcy ${ }^{40}$.

Powyższe dwa wyłączenia mają charakter ogólny i stosuje się je niezależnie od relacji pomiędzy spadkodawcą a uprawnionym do zachowku. Ustawodawca przewidział nadto dwa wyłączenia ze względu na relację pokrewieństwa pomiędzy spadkodawcą a uprawnionym do zachowku. Pierwsze wyłącznie dotyczy zachowku należnego zstępnym, przy obliczaniu którego nie dolicza się do spadku darowizn uczynionych przez spadkodawcę w czasie, kiedy nie miał zstępnych. Od powyższego wyłączenia zachodzi jednak wyjątek, zgodnie z którym wyłączenie nie dotyczy sytuacji, gdy darowizna została uczyniona na mniej niż 300 dni przed urodzeniem się zstępnego. Wskazany powyżej przepis ma na celu ochronę dziecka poczętego, ale nienarodzonego $\mathrm{w}$ dacie zdziałania darowizny. W medycynie znane są jednak przypadki ciąży trwających powyżej 300 dni zakończonych urodzeniem się żywego dziecka. W takiej sytuacji $\mathrm{w}$ razie udowodnienia przez zainteresowanego, że $\mathrm{w}$ dacie darowizny

\footnotetext{
38 Zob. P. Księżak, Zachowek w polskim prawie..., s. 304.

39 Wyrok SA w Białymstoku z dnia 12 listopada 1996 r., I ACr 308/96, LEX nr 31804.

40 Wyrok SA w Białymstoku z dnia 1 czerwca 2004 r., I ACa 285/04, LEX nr 113031.
} 
uprawniony do zachowku został już poczęty, a rodzicem niewątpliwie jest spadkodawca, uznać należałoby, że powoływanie się przez pozwanego $\mathrm{w}$ procesie o zachowek na przepis art. 994 § 2 K.c. stanowiłoby naruszenie prawa podmiotowego w myśl przepisu art. 5 K.c. Darowizna taka winna zostać wówczas doliczona do substratu zachowku. Kolejne wyłączenie dotyczy obliczania zachowku należnego małżonkowi. $W$ tym przypadku nie dolicza się do spadku darowizn, które spadkodawca uczynił przed zawarciem małżeństwa. W doktrynie podnosi się jednak, że zaliczeniu powinny podlegać darowizny uczynione przed zawarciem małżeństwa, ale na rzecz tego małżonka, który dochodzi zachowku ${ }^{41}$.

Wartość przedmiotu darowizny dolicza się według stanu z chwili jej dokonania, a według cen $\mathrm{z}$ chwili ustalenia zachowku. W doktrynie podnosi się jednak, że w sytuacjach szczególnie wyjątkowych istnieje możliwość - poprzez zastosowanie przepisu art. 5 K.c. - odstąpienia od zasady ogólnej wyrażonej w przepisie art. 995 K.c. Tytułem przykładu P. Księżak podaje obdarowanie nowym samochodem osobowym marki $X$ na 20 lat przed otwarciem spadku. W powołanej sytuacji ustalenie wartości darowizny mając na uwadze wartość nowego samochodu $X$ według cen obecnych mogłoby prowadzić do znacznego obniżenia rzeczywistej wartości ekonomicznej darowizny. Autor proponuje posłużenie się wartością nie samochodu X (który już od dawna nie jest produkowany), a samochodem Y z tego samego segmentu, który byłby aktualnym odpowiednikiem samochodu X. Pogląd autora należy uznać za oczywiście trafny, albowiem zastosowanie reguły ogólnej prowadziłoby do pokrzywdzenia wierzyciela uprawnionego z tytułu zachowku. Przy zaliczaniu darowizny na substrat zachowku obojętnym jest czy przedmiot darowizny nadal pozostaje własnością obdarowanego, a nawet, czy przedmiot darowizny nadal istnieje. Do substratu zachowku należy doliczyć również darowizny, których przedmiot nie istniał już w dacie otwarcia spadku (np. wskutek zburzenia budynku lub zniszczenia samochodu).

Słowa kluczowe: zachowek, darowizna, wartość przedmiotu darowizny, nieodpłatne zniesienie współwłasności, umowa majątkowa małżeńska

${ }_{11}$ Zob. L. Stecki, Zaliczanie darowizn pomiędzy spadkobiercami darczyńcy, Acta Universitatis Nicolai Copernici. Nauki Humanistyczno-Społeczne. Prawo 1976, z. 75, s. 134; P. Księżak, Zachowek w polskim prawie..., s. 308. 


\section{Bibliografia}

\section{Źródła}

\section{Akty prawne}

Ustawa z dnia 24 marca 1920 r. o nabywaniu nieruchomości przez cudzoziemców, tekst jednolity: Dz. U. z 2017 r. poz. 2278.

Ustawa z dnia 23 kwietnia 1964 r. - Kodeks cywilny, tekst jednolity: Dz. U. z 2019 r. poz. 1145.

Ustawa z dnia 26 października 1971 r. o uregulowaniu własności gospodarstw rolnych, Dz. U. z 1971 r. Nr 27, poz. 250 z późn. zm.

Ustawa z dnia 20 grudnia 1990 r. o ubezpieczeniu społecznym rolników, tekst jednolity: Dz. U. 2020 r. poz. 174.

Ustawa z dnia 28 sierpnia 1997 r. o organizacji i funkcjonowaniu funduszy emerytalnych, tekst jednolity: Dz. U. z 2020 r. poz. 105.

Ustawa z dnia 29 sierpnia 1997 r. - Prawo bankowe, tekst jednolity: Dz. U. z 2019 r. poz. 2357.

Ustawa z dnia 27 maja 2004 r. o funduszach inwestycyjnych i zarządzaniu alternatywnymi funduszami inwestycyjnymi, tekst jednolity: Dz. U. z 2020 r. poz. 95.

Ustawa z dnia 5 listopada 2009 r. o spółdzielczych kasach oszczędnościowo-kredytowych, tekst jednolity: Dz. U. z 2019 r. poz. 2412 z późn. zm.

\section{Orzecznictwo}

Wyrok SN z dnia 17 czerwca 1953 r., II C 534/53, LEX nr 117618.

Wyrok SN z dnia 9 lutego 1960 r., I CR 365/60, OSPiKA 1962, nr 3, poz. 74.

Wyrok SN z dnia 7 lipca 1964 r., I CR 691/63, LEX nr 238.

Uchwała SN z dnia 19 lutego 1991 r., III CZP 4/91, LEX nr 520097345.

Uchwała SN (7) z dnia 10 kwietnia 1991 r., III CZP 76/90, LEX nr 3659.

Wyrok SN z dnia 12 maja 2000 r., II CKN 542/00, LEX nr 559927.

Wyrok SN z dnia 25 listopada 2003 r., II CK 273/02, LEX nr 424449.

Wyrok SN z dnia 19 marca 2009 r., III CSK 307/08, LEX nr 492154.

Wyrok SN z dnia 25 czerwca 2015 r., V CSK 612/14, LEX nr 1771393.

Wyrok SA w Białymstoku z dnia 12 listopada 1996 r., I ACr 308/96, LEX nr 31804.

Wyrok SA w Białymstoku z dnia 1 czerwca 2004 r., I ACa 285/04, LEX nr 113031.

Wyrok SA we Wrocławiu z dnia 25 sierpnia 2009 r., I ACa 455/2009, LEX nr 2082380.

Wyrok SA w Poznaniu z dnia 14 października 2010 r., I ACa 717/2010, LEX nr 3971504.

Uchwała SN z dnia 21 czerwca 2012 r., III CZP 29/12, LEX nr 521335790.

Wyrok SA w Łodzi z dnia 18 lipca 2013 r., I ACa 244/13, LEX nr 1353761.

Wyrok SA w Gdańsku z dnia 8 lipca 2015 r., V ACa 126/15, LEX nr 1842298.

Wyrok SA w Łodzi z dnia 7 sierpnia 2015 r., I ACa 185/15, LEX nr 1808658. 


\section{Literatura}

Drozd E., Podstawowe zagadnienia konstrukcyjne umowy z następca, Rejent 1991, nr 3. Durka J., Przekazywanie gospodarstw rolnych następcy na podstawie przepisów ustawy o zaopatrzeniu emerytalnym i innych świadczeniach dla rolników i ich rodzin, Nowe Prawo 1978, nr 11/12.

Dyoniak A., Ochrona rodziny w razie śmierci jednego z matżonków, Warszawa-Poznań 1990.

Kodeks cywilny. Komentarz, t. 4. Spadki, red. A. Kidyba, Warszawa 2008.

Księżak P., Zachowek w polskim prawie spadkowym, Warszawa 2012.

Pastuszko R., Umowa przekazania gospodarstwa rolnego następcy jako podstawa wpisu w księdze wieczystej, Rejent 2004, nr 9.

Skowrońska-Bocian E., Testament w prawie polskim, Warszawa 2004.

Sokołowski K.P., Forma aktu notarialnego, uzupetnienie zachowku oraz ustalenie schedy spadkowej a "negotium mixtum cum donatione", Rejent 2011, nr 7/8.

Stecki L., Zaliczanie darowizn między spadkobiercami darczyńcy, Acta Universitatis Nicolai Copernici. Nauki Humanistyczno-Społeczne. Prawo 1976, z. 75.

Stecki L., Darowizna, Torun 1998.

Szpunar A., Uwagi o obliczaniu wysokości zachowku, Rejent 2002, nr 4.

Szpunar A., Uwagi o prawie do zachowku, Rejent 2002, nr 6.

Wójcik S., F. Zoll, Testament, Studia Prawa Prywatnego 2006, z. 2.

\section{A FEW REMARKS ON ADDING DONATIONS TO LEGITIME}

\section{Su m m a ry}

The article concentrates on the issue of inclusion of donations in the determination of the right to legitime. The issues tackled relate to the interpretation of the concept of donation in the context of calculation of legitime, especially whether it refers to the donation as defined in Art. 888 of the Civil Code or other acts made donandi causa, considering the specific purpose of the institution of legitime, intended to secure inheritance interests of the closest family of the deceased bequeather.

Key words: legitime, donation, donation value, unpaid dissolution of co-ownership, marriage property contract 


\section{НЕСКОЛЬКО ЗАМЕЧАНИЙ О ДОБАВЛЕНИИ ДАРЕНИЯ К СУБСТРАТУ ОБЯЗАТЕЛЬНОЙ ДОЛИ НАСЛЕДСТВА}

\section{Резюме}

Статья посвящена вопросу учета дарения при определении права на обязательную долю наследства. Поднятая проблематика касается трактовки понятия дарения при расчете обязательной доли наследства, а, в частности, идет ли речь о дарении, определенном в положении ст. 888 Гражданского кодекса, или также о других совершённых действиях donandi causa, учитывая особую цель института обязательной доли наследства, направленную на обеспечение наследственных интересов ближайшей семьи умершего завещателя.

Ключевые слова: обязательная доля наследства, дарение, стоимость предмета дарения, безвозмездное аннулирование совместной собственности, имущественный брачный договор 